\title{
The Regulation of Cystathionine Formation in Escherichia coli
}

\author{
By R. J. ROWBURY aND ThE LATE D. D. WOODS \\ Department of Botany, University College London, and Microbiology Unit, \\ Department of Biochemistry, University of Oxford
}

(Received 16 September 1965)

\begin{abstract}
SUMMARY
The amounts of cystathionine-forming enzymes (homoserine $\boldsymbol{O}$-transsuccinylase and cystathionine synthetase) of Escherichia coli were decreased by growth with methionine, and therefore enzymic repression applied to all the enzymes of the methionine biosynthetic pathway. Enzyme resynthesis occurred when 'inactive' organisms (organisms grown with methionine) were suspended in methionine-free culture fluid. Although the formation of all the enzymes of the pathway appears to be controlled by a single regulator gene, co-ordinate repression and derepression were not observed. Methionine also regulates its own synthesis by inhibition of the activity of homoserine O-trans-succinylase, the inhibitory effect being more marked with intact organisms than with cell-free extracts. Methionine did not influence the activity of cystathionine synthetase or the subsequent methionine-forming enzymes.
\end{abstract}

\section{INTRODUCTION}

The biosynthetic pathways of amino acids and other metabolites in bacteria are generally controlled by two regulatory mechanisms. Enzymic repression (Vogel, 1957), the diminution of enzyme synthesis by the end-product, frequently affects all the enzymes of a pathway, whereas feedback inhibition, the diminution of the activity of enzymes by end-product, usually applies only to the first enzyme (Yates \& Pardee, 1956; Wormser \& Pardee, 1958) although there may be exceptions, especially in complex pathways (Stadtman, 1963). The present work forms part of a study of the regulation of methionine biosynthesis. Previous work showed that the homocysteine methylase complex and its constituent reactions and cystathionase were subject to enzymic repression by methionine (Wijesundera. \& Woods, 1953; Rowbury \& Woods, 1961 $a, b$; Foster, Rowbury \& Woods, 1963). The effect of methionine on the formation and activity of enzymes catalysing the synthesis of cystathionine is examined in the present work. A brief report of part of this work was presented by Rowbury (1962a).

\section{METHODS}

Organisms. All the strains of Escherichia coli used in this work were maintained on slopes of Oxoid nutrient agar, subcultured monthly and stored at $4^{\circ}$ after incubation for $18 \mathrm{hr}$ at $37^{\circ}$. E. coli strain $26 / 18$ responded to homocysteine or methionine and $E$. coli strains $7 / 9,2 / 2$ and $122 / 33$ responded also to cystathionine. 
Growth of organisms. Organisms were grown on a glucose lactate salts (GL) medium supplemented with DL-homocysteine $(0.25 \mathrm{~mm})$ except where otherwise stated. Conditions for growth, harvesting and preparation of enzymic extracts were as described by Rowbury \& Woods (1961a). In certain experiments the resynthesis of enzymes after repression by methionine was studied as described by Rowbury \& Woods (1961 $a$ ).

Assay of homocysteine methylase. The overall homocysteine methylase complex was assayed in some extracts by the method of Rowbury \& Woods (1961 $a$ ) with a heated extract of organisms as source of folic acid co-factor and serine as donor of the one-carbon unit.

Cystathionase assay. Cystathionase activity was assayed by measuring pyruvate production from cystathionine as described by Wijesundera \& Woods (1962). In certain experiments pyruvate production from cysteine was measured by the same method.

Assay of the cystathionine-forming enzymes. The overall conversion of homoserine + cysteine to cystathionine by extracts from Escherichia coli strain 26/18 was assayed as described by Rowbury \& Woods $(1964 b)$. Incubation was for 3-4 hr at $37^{\circ}$ in solution $A$ which contained (in $3 \mathrm{ml}$. of $80 \mathrm{~mm}$-phosphate buffer $(\mathrm{pH} \mathrm{7.5})$ : DL-homoserine $(5 \mathrm{mM})$, L-cysteine $(3.3 \mathrm{~mm})$, sodium succinate $(50 \mathrm{mM})$, ATP (3.3 mM), glucose $(6.6 \mathrm{~mm})$, coenzyme A (0.06 mM) with $3.3 \mathrm{mg} . / \mathrm{ml}$. ultrasonic extract.

Homoserine $O$-trans-succinylase was assayed by two methods. In the first (method $a$ ), different amounts of extract from Escherichia coli strain 7/9 were incubated in solution $A$ with an excess of extract from $E$. coli strain 2/2. Activity was assessed from the amount of cystathionine formed. In the second method (method $b)$, extract from $\boldsymbol{E}$. coli strain $7 / 9$ was incubated in solution $\boldsymbol{A}$ (cysteine omitted) with $5 \mu \mathrm{c}$. of ${ }^{14} \mathrm{C}_{2,3}$-succinate added. Activity was assessed by the incorporation of ${ }^{14} \mathrm{C}$ into $\mathrm{O}$-succinylhomoserine (separated from succinate on columns of Dowex-1 resin as described by Rowbury \& Woods, 1964b). The synthesis of $O$-succinylhomoserine by whole organisms of $E$. coli strain $7 / 9$ (incubated in medium GL) was also assayed by uptake of ${ }^{14} \mathrm{C}$-succinate.

The reaction of $O$-succinylhomoserine with cysteine (cystathionine synthetase) was assayed either by measuring the cystathionine formed by various amounts of extract from Escherichia coli strain 2/2 incubated in solution $A$ with excess extract from $E$. coli strain $7 / 9(\operatorname{method} a)$, or by following cystathionine formation from cysteine + synthetic $O$-succinylhomoserine (method $b$ ), or by measuring the disappearance of isotope from ${ }^{14} \mathrm{C}-\mathrm{O}$-succinylhomoserine and the appearance of ${ }^{14} \mathrm{C}$ in free succinate on incubation with the appropriate extract plus cysteine $(\operatorname{method} c)$.

Assay of cystathionine. Assays were done as described by Rowbury \& Woods (1964b) with Escherichia coli strain 122/33.

Chromatographic methods. In certain experiments reaction products were run on paper chromatograms in $n$-butanol + propionic acid + water $(47+22+31$, by vol.) and the chromatograms either scanned for radioactivity directly with the Geiger-Müller tube of a Ratemeter Unit (type 1355B, Fleming Radio Development Ltd.) or after drying were cut up and specific regions assayed for cystathionine after elution with buffer.

Column chromatography used the acetate form of Dowex-1 resin (X8, 200-400 
mesh) and the procedure was as described by Rowbury \& Woods (1964b). In certain experiments the radioactivity of the eluate was measured by spotting samples on uniform ground-glass discs and counting at infinite thinness with a Scaler 1700 (Isotope Developments Ltd., Reading, Berkshire) for 1000 sec. Corrections were made for background activity.

Amino acids were detected on paper chromatograms by spraying with ninhydrin $\left(0.2 \% \mathrm{w} / \mathrm{v}\right.$ in $n$-butanol saturated with water) and heating at $80^{\circ}$ for $10 \mathrm{~min}$. The eluate from columns of Dowex-1 resin was assayed for amino-nitrogen by the method of Moore \& Stein (1954).

Chemicals. Most of the chemicals used were as described previously (Rowbury \& Woods, $1964 a, b) .{ }^{14} \mathrm{C}_{2,3}$-succinate was obtained from the Radiochemical Centre, Amersham, Bucks. ${ }^{14} \mathrm{C}$ - $O$-succinylhomoserine was obtained from ${ }^{14} \mathrm{C}$-succinate by growth of Escherichia coli strain 7/9 on medium GL with added DL-homocysteine $(0.25 \mathrm{mM})$ and DL-homoserine $(2.5 \mathrm{mM})$ followed by chromatographic separation as described by Rowbury \& Woods (1964 $b$ ).

\section{RESULTS}

Enzymic repression of the cystathionine-forming enzymes by growth with methionine

A cystathionaseless strain of Escherichia coli (strain 26/18) has been used previously to study cystathionine synthesis from homoserine and cysteine (Rowbury, 1961). Homocysteine methylase was known to be repressed by methionine in this strain (Rowbury \& Woods, 1961a). Overall cystathionine synthesis from homoserine + cysteine was also decreased in extracts from organisms grown with methionine, the extent of repression produced by $3 \mathrm{~mm}$-DL-methionine being about the same as for homocysteine methylase (Table 1) although at lower methionine concentrations the extent of repression was greater for homocysteine methylase.

Table 1. The repression of cystathionine formation by methionine in Escherichia coli strain $26 / 18$

Ultrasonic extracts were prepared from organisms grown on medium GL with the stated amount of methionine. Methionine synthesis (from homocysteine) was assayed as described by Rowbury \& Woods $(1961 a)$ and cystathionine formation from homoserine + cysteine measured in solution $A$. Incubation was for $3 \mathrm{hr}$ at $37^{\circ}$ in each case.

DL-methionine in growth medium (mM)

0 0.1

0.3

1

3
Methionine formed Cystathionine formed ( $\mu \mathrm{mmoles} / \mathrm{mg}$. protein/hr) ( $\mu$ mmoles/mg. protein $/ \mathrm{hr})$

The formation of cystathionine requires two enzymes: homoserine O-transsuccinylase and cystathionine synthetase (Rowbury, $1962 a$; Rowbury \& Woods, $1964 b$ ). Growth with methionine represses the formation of both of these enzymes. When Escherichia coli strain 7/9 was grown with DL-methionine (3 mM) the formation of homoserine-O-trans-succinylase was decreased by about $80 \%$; homo- 
cysteine methylase, cystathionase and cysteine deaminase were repressed by 85-90\% under these conditions (Table 2). Growth of $E$. coli strain 2/2 with methionine $(3 \mathrm{~mm})$ decreased the amount of cystathionine synthetase by $85 \%$ while the amounts of homocysteine methylase and cystathionase decreased by about $90 \%$ (Table 3 ).

\section{Table 2. Repression of homoserine $O$-trans-succinylase by methionine in Escherichia coli strain 7/9}

Extracts were prepared from $E$. coli strain $7 / 9$ after growth with the stated amount of methionine. Homocysteine methylase was assayed as described by Rowbury \& Woods (1961 $a$ ), cystathionase and cysteine deaminase were measured as described by Rowbury \& Woods $(1964 a)$ and homoserine $O$-trans-succinylase was assayed by method $a$ (see Methods) with a $3 \mathrm{hr}$ incubation at $37^{\circ}$.

\begin{tabular}{|c|c|c|c|c|}
\hline $\begin{array}{l}\text { DL-methionine } \\
\text { in growth } \\
\text { medium (mM) }\end{array}$ & $\begin{array}{c}\text { Homocysteine } \\
\text { methylase } \\
(\mu \mathrm{mmoles} / \mathrm{mg} . \\
\text { protein } / \mathbf{3} \mathrm{hr})\end{array}$ & $\begin{array}{c}\text { Cystathionase } \\
(\mu \text { moles } \\
\text { pyruvate } / \mathrm{mg} . \\
\text { protein } / \mathrm{hr})\end{array}$ & $\begin{array}{c}\text { Cysteine } \\
\text { deaminase } \\
(\mu \text { moles } \\
\text { pyruvate/mg. } \\
\text { protein } / \mathrm{hr})\end{array}$ & $\begin{array}{c}\text { Homoserine } \\
\text { O-trans- } \\
\text { succinylase } \\
(\mu \text { mmoles } / \mathrm{mg} \text {. } \\
\text { protein } / \mathrm{hr} \text { ) }\end{array}$ \\
\hline 0 & 48 & 0.8 & $0 \cdot 10$ & 50 \\
\hline 0.3 & 15 & $0 \cdot 18$ & 0.02 & 15 \\
\hline $1 \cdot 0$ & 13 & $0 \cdot 12$ & 0.015 & 12 \\
\hline $\mathbf{3} \cdot \mathbf{0}$ & 8 & $0 \cdot 10$ & 0.013 & 9 \\
\hline
\end{tabular}

Table 3. Repression by methionine of the formation of cystathionine synthetase of Escherichia coli strain $2 / 2$

Homocysteine methylase and cystathionase were assayed as for Table 2 in ultrasonic extracts prepared from $E$. coli strain $2 / 2$ grown with the stated concentration of methionine. Cystathionine synthetase (i.e. the enzyme forming cystathionine from $O$-succinylhomoserine plus cysteine) was assayed by method $a$ in solution $A$ (see Methods) with a $3 \mathrm{hr}$ incubation time at $37^{\circ}$.

$\begin{array}{cccc}\begin{array}{c}\text { DL-methionine } \\ \text { in growth } \\ \text { medium (mM) }\end{array} & \begin{array}{c}\text { Homocysteine } \\ \text { methylase } \\ (\mu \text { mmoles/mg. } \\ \text { protein/3 hr) }\end{array} & \begin{array}{c}\text { Cystathionase } \\ (\mu \text { moles } \\ \text { pyruvate/mg. } \\ \text { protein } / \mathbf{h r})\end{array} & \begin{array}{c}\text { Cystathionine } \\ \text { synthetase } \\ (\mu \text { mmoles/mg. } \\ \text { protein/3 hr) }\end{array} \\ 0 & 54 & 0.98 & 570 \\ 0 \cdot 3 & 9 & 0 \cdot 18 & 170 \\ 1 \cdot 0 & 6 & 0 \cdot 12 & 95 \\ \mathbf{3} \cdot 0 & 6 & 0 \cdot 11 & 83\end{array}$

\section{Enzyme resynthesis after repression by methionine}

Homocysteine methylase and cystathionase are rapidly reformed when' inactive' organisms (organisms which have been grown with methionine) are suspended in culture fluid free from methionine (Rowbury \& Woods, 1961 $a, b$ ). Recovery from repression also occurs with the cystathionine-forming enzymes. Organisms of Escherichia coli strain 26/18 when transferred from methionine medium to methionine-free medium rapidly regained the ability to form cystathionine from homoserine + cysteine and from $O$-succinylhomoserine + cysteine, although the latter reaction reached maximal values more quickly (Fig. 1). Homocysteine methylase increased at a similar rate to that of the overall reaction.

'Inactive' organisms of Escherichia coli strain 7/9 had much decreased amounts of homoserine $O$-trans-succinylase (Table 2) but on resuspension in methionine- 
free medium, enzyme activity rose to the de-repressed value in $3 \frac{1}{2} \mathrm{hr}$; cystathionase activity increased during this period and reached the normal value in $2 \frac{1}{2}$ hr (Fig. 2). Enzyme resynthesis also occurred when 'inactive' organisms from $E$. coli strain $2 / 2$ were suspended in methionine-free medium, and cystathionine synthetase reached maximal values more rapidly than cystathionase (Fig. 3).

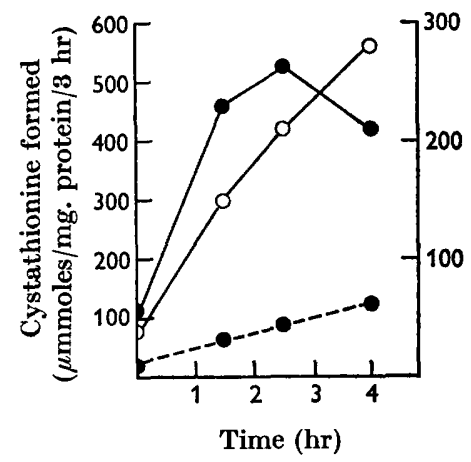

Fig. 1

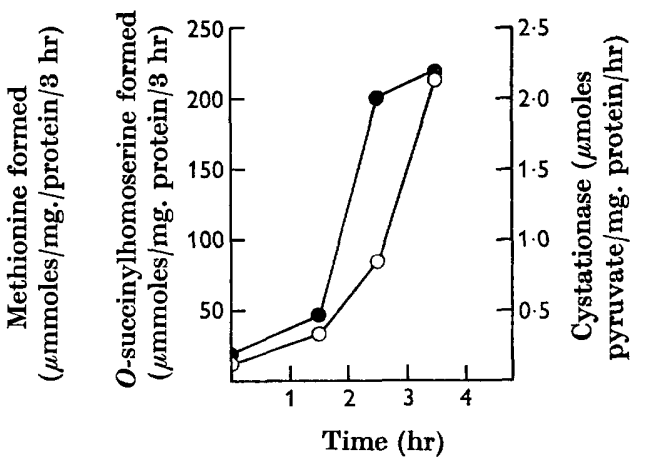

Fig. 2

Fig. 1. Resynthesis of the methionine-forming enzymes in Escherichia coli strain 26/18. Organisms grown in medium GL with DL-methionine (3.3 mM) were transferred to methionine-free culture fluid and samples taken at the stated intervals for the preparation of ultrasonic extracts. Homocysteine methylase activity $(\mathrm{O}-\mathrm{O})$ was assayed as described by Rowbury \& Woods $(1961 a)$, the overall synthesis of cystathionine from homoserine plus cysteine (-.-) measured in solution $A$ (see Methods) and the formation of cystathionine from $O$-succinylhomoserine $(2 \mathrm{mM})$ and cysteine $(3 \cdot 3 \mathrm{~mm})$ assayed by method $b$ ( - In each case incubation was for $3 \mathrm{hr}$ at $37^{\circ}$.

Fig. 2. Resynthesis of homoserine $O$-trans-succinylase after repression by methionine. Organisms of Escherichia coli strain 7/9 were harvested from medium GL containing DL-methionine $(3 \mathrm{~mm})$ and resuspended in methionine-free culture fluid. Ultrasonic extracts were prepared at the stated intervals. Homoserine $O$-trans-succinylase $(O-O)$ was assayed by method $b$ with a $3 \mathrm{hr}$ incubation period at $37^{\circ}$, and cystathionase (- measured as described by Rowbury \& Woods $(1964 \mathrm{~b})$ with a $30 \mathrm{~min}$. incubation period at $37^{\circ}$.

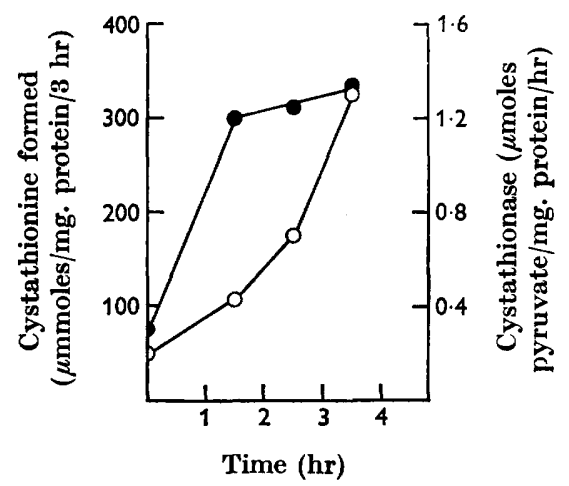

Fig. 3. Recovery from repression by methionine in Escherichia coli strain 2/2. Organisms were grown in medium GL with methionine $(3 \mathrm{~mm})$, and after harvesting resuspended in culture fluid free of methionine. Ultrasonic extracts were prepared initially and at the stated intervals and cystathionase $(\mathrm{O}-\mathrm{O})$ assayed as described for Fig. 2 and cystathionine synthetase ( -0$)$ by method $b$ (see Methods). 
The effect of methionine on the activity of the cystathionine-forming enzymes

The effect of methionine on overall cystathionine synthesis from homoserine and cysteine was treated by adding various amounts of methionine to reaction mixtures containing extract from Escherichia coli strain 26/18. After incubation the cystathionine formed was separated from the added methionine by paper chromatography and assayed with $E$. coli strain $122 / 33$. The overall reaction was markedly inhibited by methionine; $60 \%$ inhibition was produced by 2 mM-DLmethionine (Table 4).

\section{Table 4. Feedback inhibition by methionine of cystathionine synthesis in Escherichia coli strain 26/18}

Cystathionine formation by extract from $E$. coli strain 26/18 was assayed by incubation in solution $\boldsymbol{A}$ with the stated amount of methionine, separation of the product from the added methionine by paper chromatography in $n$-butanol + acetic acid + water $(2+1+1$, by vol.) and bioassay of the eluted cystathionine with $E$. coli strain 122/33.

$$
\begin{gathered}
\text { DL-methionine } \\
\text { added to reaction } \\
\text { mixture (mM) }
\end{gathered}
$$$$
\mathbf{0}
$$

2

6

10
Cystathionine formed ( $\mu \mathrm{mmoles} / \mathrm{mg}$. protein/3 hr)

150

51

14

6

Table 5. Feedback inhibition by methionine of homoserine $O$-trans-succinylase activity in intact organisms and cell-free extracts of Escherichia coli strain $7 / 9$

Enzymic activity of whole organisms was assayed by measuring the incorporation of ${ }^{14} \mathrm{C}$-succinate into $O$-succinylhomoserine by suspensions (about $1 \mathrm{mg}$. dry wt./ml.) incubated for $1 \mathrm{hr}$ at $37^{\circ}$ in medium GL with DL-homoserine $(2.5 \mathrm{mM})$ and ${ }^{14} \mathrm{C}$-succinate $(5 \mu \mathrm{c}$.) added and with the stated concentration of methionine present. Activity of ultrasonic extracts was assessed by incubation in solution $A$ (with cysteine omitted) with the addition of ${ }^{14} \mathrm{C}$-succinate $(5 \mu \mathrm{c}$.) and the stated amount of methionine; incorporation of

\begin{tabular}{|c|c|c|}
\hline \multirow{2}{*}{$\begin{array}{l}\text { DL-methionine } \\
\text { added (mM) }\end{array}$} & \multicolumn{2}{|c|}{ Homoserine $\boldsymbol{O}$-trans-succinylase } \\
\hline & $\begin{array}{r}\text { Intact organisms } \\
\text { Activity ( }\end{array}$ & $\begin{array}{l}\text { Ultrasonic extracts } \\
\text { of control) }\end{array}$ \\
\hline $\mathbf{0}$ & 100 & 100 \\
\hline 0.01 & 35 & - \\
\hline 0.05 & 8 & 100 \\
\hline 0.5 & 0 & 55 \\
\hline $1 \cdot 0$ & - & 31 \\
\hline $\mathbf{5} \cdot \mathbf{0}$ & - & 4 \\
\hline
\end{tabular}
${ }^{14} \mathrm{C}$ into $\boldsymbol{O}$-succinylhomoserine was measured. In both cases values are given as a $\%$ of the control incubation (without added methionine).

Methionine also inhibited homoserine $O$-trans-succinylase, the first reaction of the biosynthetic pathway. Synthesis of $O$-succinylhomoserine (assayed by incorporation of ${ }^{14} \mathrm{C}$-succinate) was decreased to $50 \%$ by $0.5 \mathrm{~mm}$-DL-methionine and to $5 \%$ by $5 \mathrm{~mm}$-methionine in extracts of Escherichia coli strain 7/9 (Table 5). Whole organisms of $E$. coli strain $7 / 9$ accumulate $O$-succinylhomoserine in the 
culture fluid (Rowbury, 1964c) and this accumulation is also subject to feedback inhibition by methionine. Accumulation was decreased to $35 \%$ by $0.01 \mathrm{~mm}$-DLmethionine and to $8 \%$ by 0.05 mm-methionine (Table 5 ).

The effect of methionine on cystathionine synthetase (the enzyme forming cystathionine from $O$-succinylhomoserine + cysteine) was also tested with extracts from Escherichia coli strains 26/18 and 2/2. With extract from $E$. coli strain 26/18 cystathionine formation (assayed by the disappearance of $O$-succinylhomoserine and the formation of ${ }^{14} \mathrm{C}$-succinate) from $O$-succinylhomoserine was not decreased by the presence of $20 \mathrm{~mm}-\mathrm{DL}-\mathrm{methionine}$ (Table 6). Similarly the activity of cystathionine synthetase from $E$. coli $2 / 2$ was unaffected by the presence of methionine in reaction mixtures. The formation of cystathionine from $O$-succinylhomoserine in the presence of methionine was confirmed by paper chromatography and by isotope experiments with $O$-succinylhomoserine labelled with ${ }^{14} \mathrm{C}$ in the homoserine residue.

Table 6. The effect of methionine on the formation of cystathionine and succinate from $O$-succinylhomoserine + cysteine by Escherichia coli strain 26/18

\begin{abstract}
Extract from $E$. coli strain $26 / 18$ was incubated for $2 \mathrm{hr}$ at $37^{\circ}$ with ${ }^{14} \mathrm{C}-\mathrm{O}$-succinylhomoserine $(2 \mathrm{~mm})+$ cysteine $(3 \cdot 3 \mathrm{~mm})$. The products were separated by paper chromatography in $n$-butanol + propionic acid + water $(47+22+31$, by vol.) and the radioactivity assessed as described in methods.
\end{abstract}

$$
\begin{aligned}
& \text { DL-methionine } \\
& \text { added to reaction } \\
& \text { mixture (mM) }
\end{aligned}
$$$$
\begin{array}{r}
0 \\
6 \\
20
\end{array}
$$

\author{
Formation \\ of succinate \\ ( $\mu$ moles/ml.) \\ $0 \cdot 69$ \\ $0 \cdot 70$ \\ $0 \cdot 72$
}

\title{
DISCUSSION
}

Previous work on the regulation of methionine biosynthesis in Escherichia coli has shown that growth with methionine repressed the formation of homocysteine methylase and cystathionase (Rowbury \& Woods, 1961 $a, b$ ). The methylation of homocysteine involves the functioning of two enzymes concerned, respectively, with the synthesis, and the transfer of methyl groups (as derivatives of folic acid coenzymes). Both enzymes are repressed by growth with methionine (Foster, Rowbury \& Woods, 1963). After growth with cobalamin, a cobamide enzyme functions in the methyl-group transfer; this enzyme also is subject to enzymic repression by methionine (Rowbury, 1962b). The present work shows that the cystathionine-forming enzymes are also subject to repression, so that methionine regulates the synthesis of at least six enzymes. Two observations suggest, however, that co-ordinate repression (Ames \& Garry, 1959) does not occur. First, enzyme A of homocysteine methylase (Foster et al. 1963) is normally present in excess and can be repressed by concentrations of methionine which do not influence enzyme B. Secondly, during enzyme resynthesis after repression the methionine-forming enzymes are not re-formed at the same rate (Figs. 1, 2, 3). The genes concerned with methionine synthesis in $\boldsymbol{E}$. coli do not constitute a single group on the chromosome and consequently co-ordinate repression which appears to be de- 
pendent on such close linkage (Monod, Jacob \& Gros, 1962) would not be expected. Although the methionine-synthesis genes do not appear to constitute a single operon in $E$. coli their function is controlled by a single regulator gene. Thus certain norleucine-resistant mutants of $\boldsymbol{E}$. coli are not repressible by methionine; the mutation appears to lead to failure to form an apo-repressor with consequent oversynthesis (and non-repressibility) of all the enzymes for methionine synthesis (Rowbury, 1965).

The present work also shows that methionine inhibits the activity of the first enzyme peculiar to the methionine synthesis pathway, homoserine $O$-transsuccinylase, but does not affect cystathionine synthetase or the other biosynthetic enzymes (Wijesundera \& Woods, 1962; Rowbury \& Woods, 1964a). Homoserine $O$-trans-succinylase of whole organisms was much more sensitive to feedback inhibition by methionine than the enzyme in cell-free extract, possibly due to the high substrate levels used with in vitro experiments. Although homoserine $O$-trans-succinylase was so sensitive to methionine, feedback inhibition alone does not adequately regulate methionine formation for non-repressible strains excrete methionine while still sensitive to feedback inhibition (Rowbury, 1965).

The present work further confirms the rôle of cystathionine as a methionine precursor in Escherichia coli and the pathway and mode of regulation appears to be the same as in Salmonella typhimurium (Rowbury, 1964a). The other product of cystathionine synthetase is free succinate (Rowbury, 1964b; and Table 6) so that the scheme for cystathionine biosynthesis suggested by Rowbury \& Woods $(1964 b)$ may be considered to be established.

\section{REFERENCES}

AMEs, B. N. \& GarRy, B. (1959). Coordinate repression of the synthesis of four histidine biosynthetic enzymes by histidine. Proc. natn. Acad. Sci. U.S.A. 45, 1453.

Foster, M. A., Rowbury, R. J. \& Woods, D. D. (1963). Control of the methylation of homocysteine in Escherichia coli. J. gen. Microbiol. 31, xix.

Monod, J., JACOB, F. \& Gros, F. (1962). Structural and rate-determining factors in the biosynthesis of adaptive enzymes. In The Structure and Biosynthesis of Macromolecules. Biochem. Soc. Symp. 20, 104.

Moore, S. \& Stein, W. H. (1954). A modified reagent for the photometric determination of amino-acids and related compounds. J. biol. Chem. 211, 907.

RowbURY, R.J. (1961). The synthesis of cystathionine by Escherichia coli. Biochem. J. 81, 42 P.

Rowbury, R. J. (1962a). Control of cystathionine formation in Escherichia coli by methionine. Biochem. J. 82, $24 \mathrm{P}$.

RowbURY, R. J. (1962b). Factors influencing the control of methionine synthesis in micro-organisms. D.Phil. Thesis, Oxford University.

Rowbury, R. J. (1964a). Synthesis of cystathionine and its control in Salmonella typhimurium. Nature, Lond. 203, $97 \%$.

Rowbury, R. J. (1964b). The metabolism of $O$-succinylhomoserine by Escherichia coli. Biochem. J. 93, 20 P.

Rowbury, R. J. $(1964 c)$. The accumulation of $O$-succinylhomoserine by Escherichia coli and Salmonella typhimurium. J. gen. Microbiol. 37, 171.

Rowbury, R. J. (1965). Resistance to norleucine and control of methionine synthesis in Escherichia coli. Nature, Lond. 206, 962.

Rowbury, R. J. \& Woods, D. D. (1961 $a$ ). Further studies on the repression of methionine synthesis in Escherichia coli. J. gen. Microbiol. 24, 129. 
Rowbury, R. J. \& Woods, D. D. (1961 b). Repression of cystathionase production in Escherichia coli. Biochem. J. 79, 36P.

Rowbury, R. J. \& Woods, D. D. (1964a). Repression by methionine of cystathionase formation in Escherichia coli. J. gen. Microbiol. 35, 145.

Rowbury, R. J. \& Woods, D. D. (1964b). $O$-succinylhomoserine as an intermediate in the synthesis of cystathionine by Escherichia coli. J. gen. Microbiol. 36, 341.

Stadtman, E. R. (1963). Enzyme multiplicity and function in the regulation of divergent metabolic pathways. Bact. Rev. 27, 170.

VoGeL, H. J. (1957). Repression and induction as control mechanisms of enzymic biogenesis: the 'adaptive' formation of acetylornithinase. In The Chemical Basis of Heredity, Ed. W. D. McElroy and B. Glass, p. 276. Baltimore: The Johns Hopkins Press.

WiJesundera, S. \& Woods, D. D. (1953). The effect of growth on a medium containing methionine on the synthesis of this amino acid by Bacterium coli. Biochem. J. 55, viii.

WiJesundera, S. \& Woods, D. D. (1962). The catabolism of cystathionine by Escherichia coli. J. gen. Microbiol. 29, 353.

Wormser, E. H. \& Pardee, A. B. (1958). Regulation of threonine biosynthesis in Escherichia coli. Arch. Biochem. Biophys. 78, 416.

Yates, R. A. \& Pardee, A. B. (1956). Control of pyrimidine biosynthesis in Escherichia coli by a feedback mechanism. J. biol. Chem. 221, 757 . 